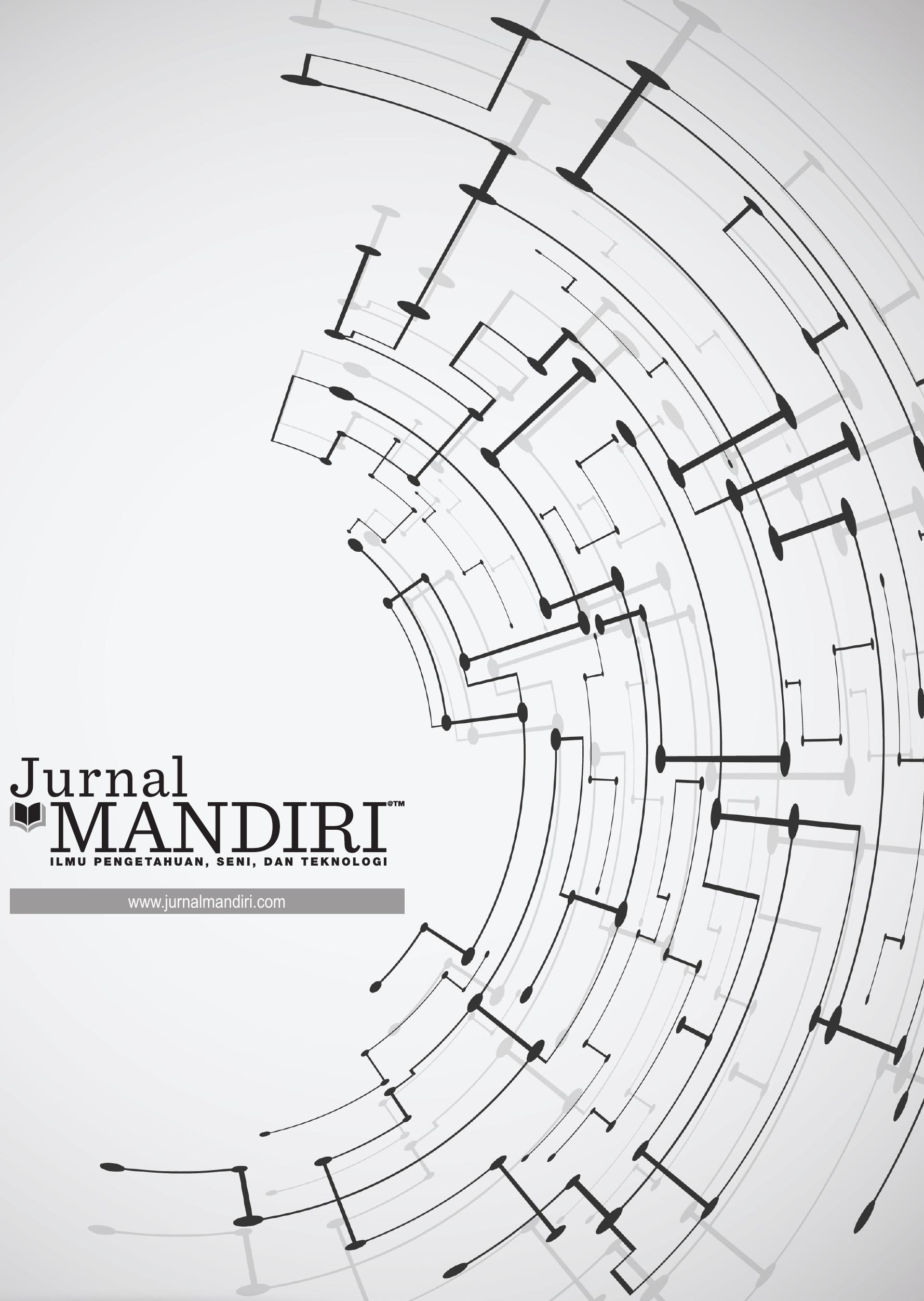


ISSN : 2580-3220, E-ISSN : 2580-4588

J. Mandiri., Vol. 4, No. 1, Juni 2020 (38 - 51)

C2018 Lembaga Kajian Demokrasi

dan Pemberdayaan Masyarakat (LKD-PM)

DOI : https://doi.org/10.33753/mandiri.v4i1.99

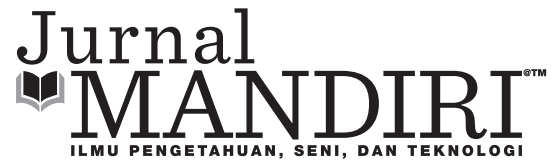

\title{
Pengaruh Kepercayaan Pelanggan dan Promosi Terhadap Keputusan Pembelian Konsumen Pada Online Shop Mikaylaku Dengan Minat Beli Sebagai Variabel Intervening
}

\author{
Dede Solihin \\ Fakultas Ekonomi, Universitas Pamulang \\ dosen02447@unpam.ac.id
}

\begin{abstract}
Abstrak
Tujuan penelitian ini adalah untuk mengetahui pengaruh kepercayaan dan promosi terhadap keputusan pembelian dengan menggunakan minat beli sebagai variabel intervening. Metode yang digunakan dalam penelitian ini menggunakan metode analisis jalur. Sampel yang digunakan sebanyak 100 responden. Sementara pengumpulan data dengan cara kuesioner. Hasil penelitian menunjukkan bahwa kepercayaan memiliki pengaruh yang positif dan signifikan terhadap minat beli dengan nilai $t_{\text {hitung }} 6,066>t_{\text {tabel }} 1,984$ dan nilai sig $0,000<0,05$. Promosi memiliki pengaruh yang positif dan signifikan terhadap minat beli dengan nilai $t_{\text {hitung }}$ $3,902>t_{\text {tabel }} 1,984$ dan nilai sig 0,000 $<0,05$. Minat beli memiliki pengaruh yang positif dan signifikan terhadap keputusan pembelian dengan nilai $t_{\text {hitung }} 3,209>t_{\text {tabel }} 1,984$ dan nilai sig $0,002<0,05$. Kepercayaan pelanggan memiliki pengaruh yang positif dan signifikan terhadap keputusan pembelian dengan nilai $t_{\text {hiturg }} 4,987>t_{\text {tabel }}$ 1,984 dan nilai sig 0,000 < 0,05. Promosi memiliki pengaruh yang positif dan signifikan terhadap keputusan pembelian dengan nilai $t_{\text {hitung }} 2,531>t_{\text {tabel }} 1,984$ dan nilai sig 0,013 $<0,05$. Minat beli mampu memediasi pengaruh kepercayaan terhadap keputusan pembelian dibuktikan dari hasil uji sobel 2,492>1,96. Minat beli mampu memediasi pengaruh promosi terhadap keputusan pembelian dibuktikan dari hasil uji sobel 2,77 > 1,96. Simpulan dari penelitian ini adalah semakin tinggi tingkat kepercayaan pelanggan maka akan semakin tinggi pula minat beli dan keputusan pembelian pelanggan. Semakin tinggi promosi yang dilakukan maka akan semakin tinggi pula minat beli dan keputusan pembelian pelanggan. Semakin tinggi minat beli maka akan semakin tinggi pula keputusan pembelian.
\end{abstract}

Kata Kunci : Kepercayaan, Promosi, Minat Beli, Keputusan Pembelian

\begin{abstract}
The purpose of this study was to determine the effect of trust and promotion on purchasing decisions by using buying interest as an intervening variable. The method used in this study uses the path analysis method. The sample used was 100 respondents. While data collection by questionnaire. The results showed that trust had a positive and significant influence on buying interest with a $t_{\text {count }}$ of $6.066>t_{\text {table }} 1.984$ and a sig value of 0.000 $<0.05$. Promotion has a positive and significant influence on buying interest with a $t_{\text {count }}$ of $3.902>t_{\text {table }} 1.984$ and a sig value of $0.000<0.05$. Purchasing interest has a positive and significant influence on purchasing decisions with a $t_{\text {count }}$ of $3.209>1.984$ and a sig value of $0.002<0.05$. Customer trust has a positive and significant influence on purchasing decisions with a $t_{\text {count }}$ of $4.987>t_{\text {table }} 1.984$ and a sig value of $0.000<0.05$. Promotion has a positive and significant influence on purchasing decisions with a $t_{\text {count }}$ of $2.531>t_{\text {table }} 1.984$ and a sig value of $0.013<0.05$. Purchasing interest is able to mediate the effect of trust on purchasing decisions as evidenced by the results of the sobel test 2.492> 1.96. Purchasing interest is able to mediate the effect of promotion on purchasing decisions as evidenced from the results of the sobel test of 2.77> 1.96. The conclusion from this study
\end{abstract}


is the higher the level of customer confidence, the higher the buying interest and customer purchasing decisions. The higher the promotion, the higher buying interest and customer purchasing decisions will be. The higher the buying interest, the higher the buying decision.

Keywords : Trust, Promotion, Purchase Interest, Purchase Decision

\section{PENDAHULUAN}

Seiring dengan perkembangan era teknologi yang setiap tahun selalu meningkat di Indonesia, tidak mengherankan jika banyak masyarakat yang memanfaatkan hal tersebut guna memenuhi aktifitasnya sehari-harinya. Menurut Euromonitor, penjualan online di Indonesia telah mencapai \$1,1 miliar sejak 2014. Selain itu, berdasarkan data dari Badan Pusat Statistik (BPS), sektor e-commerce di Indonesia telah tumbuh hingga $17 \%$ dalam 10 tahun terakhir, dengan jumlah total perusahaan e-commerce mencapai 26,2 juta unit. Sementra itu pada tahun 2018, e-commerce di Indonesia mencatat pertumbuhan yang sangat cepat dan diperkirakan akan terus tumbuh dengan meningkatnya jumlah pengusaha dan pengusaha mikro, kecil dan menengah (UMKM) di negara ini. Ini bisa dilihat pada grafik di bawah ini:

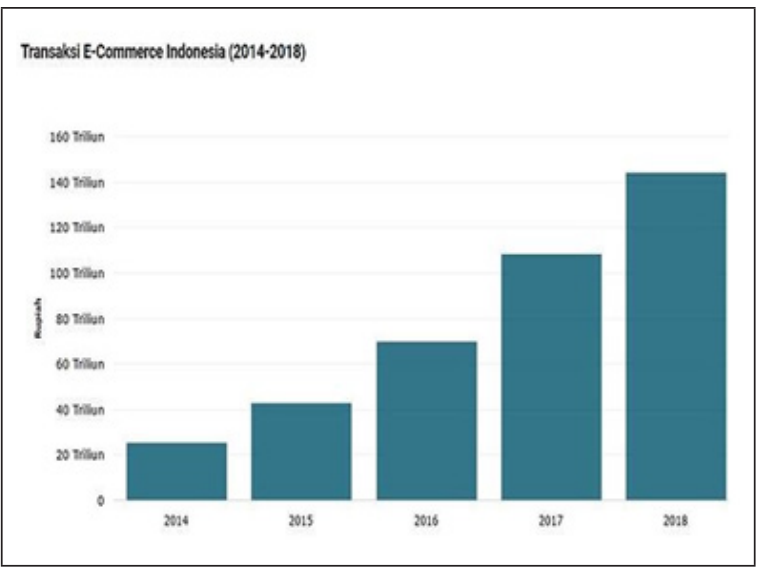

Gambar 1. Pertumbuhan Bisnis e-commerce

Dengan melihat data tersebut, dapat dikatakan bahwa bisnis e-commerce di Indonesia selalu mengalami peningkatan setiap tahunnya. Dan, tentu saja, ini merupakan peluang bagi para pelaku usaha, karena menggunakan media digital dapat memudahkan mereka menemukan pembeli potensial mereka.

Ada banyak cara yang bisa dilakukan pelaku usaha untuk menawarkan produknya secara online seperti melalui media sosial yang saat ini sedang populer baik dari kalangan remaja maupun orang dewasa dalam menjalankan bisnis biasanya menggunakan Facebook, Twitter, dan Instagram untuk mengiklankan dan menjual produk mereka. Berkembangnya toko online di media sosial (social commerce) yang menjual berbagai produk menjadikan persaingan bisnis online semakin tinggi.

Hal tersebut dimanfaatkan betul oleh Mikaylaku untuk menawarkan produknya secara online kepada pelanggan. Produk yang dijual secara online pada online shop Mikaylaku sendiri adalah produk pakaian dengan berbagai macam merek dengan bekerjasama dengan Shopee Indonesia.

Namun didalam perjalanan bisnisnya Mikaylaku mengalami banyak sekali permasalahan mengenai menurunnya keputusan pembelian konsumen setiap bulan. Hal tersebut tentu saja kalau dibiarkan secara terus menerus tanpa adanya strategi pemasaran yang baik akan merugikan keberlangsungan perusahaan. Data penjualan yang menurun pada online shop Mikaylaku dapat terlihat dari data dibawah ini:

\begin{tabular}{|l|c|c|}
\hline \multicolumn{3}{|c|}{ Tabel 1. Data Penjualan Mikaylaku 2019 } \\
\hline \multicolumn{1}{|c|}{ Bulan } & Omset & $\%$ \\
\hline Januari & 750.000 .000 & - \\
\hline Februari & 885.000 .000 & 135.000 .000 \\
\hline Maret & 772.000 .000 & -113.000 .000 \\
\hline April & 748.000 .000 & -24.000 .000 \\
\hline Mei & 934.000 .000 & 186.000 .000 \\
\hline Juni & 980.000 .000 & 46.000 .000 \\
\hline Juli & 800.000 .000 & -180.000 .000 \\
\hline Agustus & 150.000 .000 & -650.000 .000 \\
\hline September & 100.000 .000 & -50.000 .000 \\
\hline Oktober & 95.000 .000 & -5.000 .000 \\
\hline November & 93.600 .000 & -1.400 .000 \\
\hline Desember & 88.000 .000 & -50.600 .000 \\
\hline & & Sumber: Mikaylaku, 2020 \\
\hline
\end{tabular}

Tabel 1 tersebut menunjukkan penjualan yang menurun setiap bulannya dimana penurunan terjadi di bulan Juli sampai dengan bulan Desember. 
Hal tersebut tentu saja memberikan dampak yang buruk bagi kelangsungan pelaku bisnis yang jika dibiarkan terus menerus akan membuat perusahaan tersebut gulung tikar.

Banyak faktor yang mempengaruhi keputusan pembelian, mulai dari persaingan dari perusahaan sejenis, gaya hidup, faktor ekonomi dan faktor sosial. Disamping itu faktor internal juga sangat dominan mempengaruhi seperti variabel kepercayaan pelanggan, promosi dan minat beli.

"Pada belanja online minat pembelian merupakan prediktor penting dari perilaku pembelian aktual yang mengacu pada hasil penilaian konsumen mengenai pencarian informasi, kualitas produk dan evaluasi produk yang selanjutnya akan menghasilkan peningkatan minat pembelian dan memungkinkan untuk mendorong suatu keputusan pembelian dalam suatu produk", (Zeng dan Yuen, 2015).

"Faktor kepercayaan dalam toko online berkaitan erat dengan keyakinan konsumen pada perantara dan vendor online" (Chen dan Dhillon, 2003). "Semakin tinggi kepercayaan konsumen, maka semakin tinggi tingkat minat pembelian konsumen" (Gefen dan Straub, 2004). "Kepercayaan perlu ada ketika memutuskan pesanan produk online dan ketika konsumen mengirimkan informasi keuangan dan data pribadi lainnya dalam melakukan transaksi” (Egger, 2006:55). "Implikasi kepercayaan memiliki dampak yang signifikan terhadap keinginan konsumen untuk melakukan transaksi melalui internet", (Cheng dan Yee, 2014).

Rendahnya kepercayaan pelanggan dalam melakukan pembelian dikarenakan adanya perasaan ragu-ragu akan dari kualitas produk yang dibeli. Pelanggan merasa takut jika barang yang dibeli tidak sesuai dengan ekspetasi, oleh karena itu, faktor kepercayaan untuk pembelian online masih menjadi masalah serius yang perlu dipertimbangkan penjual online. Faktor-faktor ini penting untuk mempengaruhi proses belanja online.

"Promosi merupakan salah satu faktor penentu keberhasilan progam pemasaran atau strategi pemasaran hal ini dikarenakan promosi adalah komunikasi yang persuasif, mengajak, mendesak, membujuk dan meyakinkan seseorang" (Mursid, 2016:96).

Jika suatu produk yang bagus sekalipun tanpa adanya promosi yang efektif akan membuat produk tersebut tidak akan laku dijual. Dengan adanya promosi maka pelanggan akan mengetahui seberapa bermanfaatnya produk tersebut untuk dimiliki. Dengan adanya promosi maka akan mengubah sikap pelanggan dan mendorong pelanggan untuk bertindak atau membeli produk tersebut.

Maka dari itu promosi yang dilakukan oleh Mikaylaku harus mampu mempengaruhi dan menarik para pelanggan dalam mengunjungi situs Mikaylaku dalam melakukan pembelian. Seperti memberikan promo diskon potongan harga produk dan gratis ongkir yang kesemuanya harus sesuai dengan harapan pelanggan sehingga akan menyebabkan tingkat keputusan pembelian oleh konsumen menjadi tinggi.

\section{METODE}

Metode penelitian ini menggunakan metode asosiatif kausal. Sugiyono (2016:59) menyatakan bahwa "Hubungan kausal adalah hubungan yang bersifat sebab dan akibat, jadi disini terdapat variabel independen (variabel yang mempengaruh) dan variabel dependen (variabel yang dipengaruhi)". Populasi dalam penelitian ini adalah seluruh pelanggan atau pembeli pada online shop Mikaylaku. Teknik pengambilan sampel menggunakan metode purposive sampling. Sementara untuk menentukan besarnya jumlah sampel menggunakan rumus sebagai berikut:

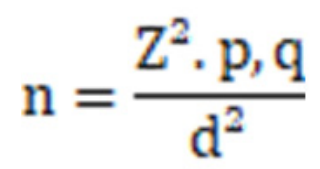

Keterangan:

$\mathrm{n}=$ jumlah sampel

$\mathrm{Z}=$ harga standar normal $(1,976)$

$\mathrm{P}=$ estimator proporsi populasi $(0,5)$

$\mathrm{d}=$ interval atau penyimpangan $(0,10)$

$\mathrm{q}=1-\mathrm{p}=(0,5)$

Jadi besar sampel dapat dihitung sebagai berikut: 


$$
\mathrm{n}=\frac{1,976^{2}(0,5)(0,5)}{0,1^{2}} \mathrm{n}=97,5
$$

Hasil perhitungan 97,5 dibulatkan menjadi 100 responden. Instrumen dalam penelitian ini dengan cara membagikan kuesioner kepada pelanggan online shop Mikaylaku secara online. Teknik analisis data yang digunakan dalam penelitian ini menggunakan analisis jalur dengan menggunakan model sebagai berikut.

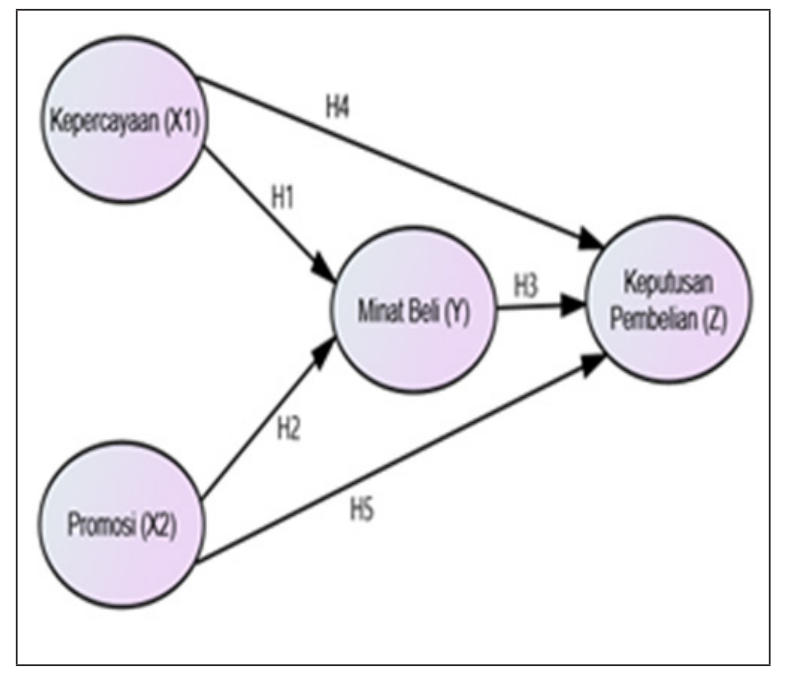

Gambar 2. Model Analisis Jalur

\section{HASIL dan PEMBAHASAN}

\section{Kepercayaan Pelanggan}

Kotler \& Keller (2016:225) mengatakan bahwa, "Trust is the willingness of a firm to rely on a business partner. It depends on a number of interpersonal and interorganizational factors, such as the firm's perceived competence, integrity, honesty and benevolence". Kepercayaan konsumen menurut Mowen (2012:312) adalah "semua pengetahuan yang dimiliki oleh konsumen dan semua kesimpulan yang dibuat konsumen tentang objek, atribut, dan manfaatnya”.

Menurut Barnes (2013:149), beberapa elemen penting dari kepercayaan pelanggan adalah sebagai berikut:

1. "Kepercayaan merupakan perkembangan dari pengalaman dan tindakan masa lalu”.

2. "Watak yang diharapkan dari partner seperti dapat dipercaya dan diandalkan".
3. "Kepercayaan melibatkan kesediaan untuk menempatkan diri dalam resiko".

4. "Kepercayaan melibatkan perasaan aman dan yakin pada diri partner".

Wong (2017) menyatakan, faktor yang membentuk kepercayaan seseorang terhadap merek suatu perusahaan ada tiga yaitu:

1. Kesungguhan/ketulusan (benevolence)

"Kebaikan hati merupakan kemauan penjual dalam memberikan kepuasan yang saling menguntungkan antara dirinya dengan konsumen. Profit yang diperoleh penjual dapat dimaksimumkan, tetapi kepuasan konsumen juga tinggi. Penjual bukan semata-mata mengejar profit maksimum semata, melainkan juga memiliki perhatian yang besar dalam mewujudkan kepuasan konsumen".

2. Kemampuan (ability)

"Kemampuan mengacu pada kompetensi dan karakteristik penjual/organisasi dalam mempengaruhi dan mengotori wilayah yang spesifik. Dalam hal ini, bagaimana penjual mampu menyediakan, melayani, sampai mengamankan transaksi dari gangguan pihak lain. Artinya bahwa konsumen memperoleh jaminan kepuasan dan keamanan dari penjual dalam melakukan transaksi”.

3. Integritas (integrity)

"Integritas berkaitan dengan bagaimana perilaku atau kebiasaan penjual dalam menjalankan bisnisnya. Informasi yang diberikan kepada konsumen apakah benar sesuai dengan fakta atau tidak. Kualitas produk yang dijual apakah dapat dipercaya atau tidak"

\section{Promosi}

Menurut Kotler dan Amstrong (2016:408), "promosi adalah suatu alat untuk berkomunikasi pembeli dan perusahaan lain yang bertujuan untuk merubah memberikan informasi secara lugas". Sementara Cummins (2014:14) mendefinisikan "promosi sebagai serangkaian teknik yang digunakan untuk mencapai sasaran penjualan atau pemasaran dengan menggunakan biaya yang efektif, dengan memberikan nilai tambah pada produk atau jasa baik kepada perantara atau 
pemakai langsung, biasanya tidak dibatasi dalam jangka waktu tertentu".

Adapun tujuan daripada promosi menurut Kotler dan Armstrong (2016:205) yaitu sebagai berikut:

1. "Mendorong pembelian pelanggan jangka pendek atau meningkatkan hubungan pelanggan jangka panjang".

2. "Mendorong pengecer menjual barang baru dan menyediakan lebih banyak persediaan".

3. "Mengiklankan produk perusahaan dan memberikan ruang rak yang lebih banyak".

4. "Untuk tenaga penjualan, berguna untuk mendapatkan lebih banyak".

5. "Dukungan tenaga penjualan bagi produk lama atau baru atau mendorong wiraniaga mendapatkan pelanggan baru".

Menurut Kotler dan Armstrong (2016:205), indikator-indikator dari promosi adalah sebagai berikut:

\section{Periklanan (Advertising)}

"Semua bentuk presentasi dan promosi nonpersonal yang dibayar oleh sponsor untuk mempresentasikan gagasan, barang atau jasa, periklanan dianggap sebagai manajemen citra yang bertujuan menciptakan dan memelihara cipta dan makna dalam benak konsumen, bentuk promosi yang digunakan mencakup media masa, broadcast, internet, outdoor, dan bentuk lainnya".

2. Penjualan Pribadi (Personal Selling)

"Presentasi personal oleh tenaga penjualan dengan tujuan menghasilkan penjualan dan membangun hubungan dengan konsumen, bentuk promosi yang digunakan mencakup presentasi, pameran dagang, dan program insentif".

3. Promosi Penjualan (Sales Promotion) "Insentif-insentif jangka pendek untuk mendorong pembelian atau penjualan suatu produk atau jasa, bentuk promosi yang digunakan mencakup diskon, kupon, pajangan, demonstrasi, kontes, dan undian".

4. Pemasaran Langsung (Direct Marketing) "Hubungan langsung dengan sasaran konsumen dengan tujuan untuk memperoleh tanggapan segera dan membina hubungan yang abadi dengan konsumen, bentuk promosi yang digunakan mencakup, brosur, pemasaran telepon, kios, pemasaran seluler, dan lainnya".

5. Publisitas (Publicity)

"Membangun hubungan yang baik dengan berbagai pihak perusahaan supaya memperoleh publisitas yang menguntungkan, membangun citra perusahaan yang bagus, dan menangani atau meluruskan rumor, cerita, serta event yang tidak menguntungkan, bentuk promosi yang digunakan mencakup siaran pers, sponsor, acara khusus, dan web".

\section{Minat Beli}

Kotler dan Keller (2016:137) menyatakan bahwa "minat beli adalah perilaku konsumen yang muncul sebagai respon terhadap objek yang menunjukkan keinginan seseorang untuk melakukan pembelian". Sedangkan pengertian minat beli menurut Sciffman dan Kanuk (2015:228) adalah: "Suatu model sikap seseorang terhadap objek barang yang sangat cocok dalam mengukur sikap terhadap golongan produk, jasa, atau merek tertentu".

"Tahapan-tahapan produsen dalam menentukan minat beli atau menentukan dorongan konsumen dalam melakukan pembelian terhadap produk atau jasa yang ditawarkan, dapat kita lihat pada konsep atau model AIDA yang dikembangkan oleh Kotler (2016:568), yaitu":

1. "Attention, tahap ini merupakan tahap awal dalam menilai suatu produk atau jasa sesuai dengan kebutuhan calon pelanggan, selain itu calon pelanggan juga mempelajari produk atau jasa yang ditawarkan".

2. "Interest, dalam tahap ini calon pelanggan mulai tertarik untuk membeli produk atau jasa yang ditawarkan, setelah mendapatkan informasi yang lebih terperinci mengenai produk atau jasa yang ditawarkan".

3. "Desire, calon pelanggan mulai memikirkan serta berdiskusi mengenai produk atau jasa yang ditawarkan, karena hasrat dan keinginan untuk membeli mulai timbul". "Tahap ini ditandai dengan munculnya minat yang kuat dari calon pelanggan untuk membeli dan 
mencoba produk atau jasa yang ditawarkan".

4. "Action, pada tahap ini calon pelanggan telah mempunyai kemantapan yang tinggi untuk membeli atau menggunakan produk atau jasa yang ditawarkan".

Ferdinand (2006) menyatakan bahwa minat beli pelanggan dapat diidentifikasi melalui indikator berikut:

1. "Minat transaksional, yaitu kecenderungan seseorang untuk membeli produk".

2. "Minat refrensial, yaitu kecenderungan seseorang untuk mereferensikan produk kepada orang lain".

3. "Minat preferensial, yaitu minat yang menggambarkan perilaku seseorang yang memiliki prefrensi utama pada produk tersebut, preferensi ini hanya dapat diganti jika terjadi sesuatu dengan produk preferensinya".

4. "Minat eksploratif, minat ini menggambarkan perilaku seseorang yang selalu mencari informasi mengenai produk yang diminatinya dan mencari informasi untuk mendukung sifatsifat positif dari produk tersebut".

\section{Keputusan Pembelian}

Kotler dan Keller (2016:170) memberikan definisi keputusuan pembelian "In the evaluation stage, the consumers from preferences among the brans in the choice set and may also from an intention to buy the most preferred brand". Sedangkan menurut Tjiptono (2015), "keputusan pembelian konsumen merupakan sebuah tindakan yang dilakukan konsumen untuk membeli suatu produk serta dalam proses pengambilan keputusan yang menentukan adalah kegiatan tersebut".

Menurut Kotler dan Keller (2016:235) indikator dari proses keputusan pembelian konsumen dapat dilihat dari ciri-ciri sebagai berikut:

1. Pengenalan Kebutuhan

"Proses pembelian dimulai saat pembeli mengenali sebuah masalah atau kebutuhan, pembeli merasakan perbedaan antara keadaan aktualnya dengan keadaan yang diinginkannya".

2. Pencarian Informasi

"Seseorang yang tergerak oleh stimulus akan berusaha mencari lebih banyak informasi yang terlibat dalam pencarian akan kebutuhan, pencarian informasi merupakan aktivitas termotivasi dari pengetahuan yang tersimpan dalam ingatan dan perolehan informasi dari lingkungan".

3. Evaluasi Alternatif

"Evaluasi alternatif Merupakan proses dimana suatu alternatif pilihan disesuaikan dan dipilih untuk memenuhi kebutuhan konsumen".

4. Keputusan Membeli

"Keputusan untukmembeli di sini merupakan proses dalam pembelian yang nyata, jadi, setelah tahap-tahap di muka dilakukan, maka konsumen harus mengambil keputusan apakah membeli atau tidak, konsumen mungkin juga akan membentuk suatu maksud membeli dan cenderung membeli merek yang disukainya”.

5. Perilaku Pasca Pembelian

"Setelah pembelian produk terjadi, konsumen akan mengalami suatu tingkat kepuasan atau ketidakpuasan. Kepuasan atau ketidakpuasan pembeli terhadap produk akan mempengaruhi tingkah laku berikutnya. Konsumen yang merasa puas akan memperlihatkan peluang membeli yang lebih tinggi dalam kesempatan berikutnya”.

\section{Hasil}

\section{Uji Validitas}

Menurut Sugiyono (2017:267) "validitas merupakan derajat ketepatan antara data yang terjadi pada obyek penelitian dengan data yang dapat dilaporkan oleh peneliti”. Untuk mengetahui apakah data yang digunakan valid dengan membandingkan antara $\mathrm{r}_{\text {hitung }}$ dengan $\mathrm{r}_{\text {tabel }}$ dengan tingkat kesalahan (signifikan) 5\%.

\begin{tabular}{|c|c|c|c|}
\hline \multicolumn{4}{|c|}{ Tabel 2. Uji Validitas Kepercayaan } \\
\hline Bulan & $\mathbf{r}_{\text {tabel }}$ & $\mathbf{r}_{\text {tabel }}$ & Keputusan \\
\hline P1 & 0,746 & 0,196 & Valid \\
\hline P2 & 0,718 & 0,196 & Valid \\
\hline P3 & 0,716 & 0,196 & Valid \\
\hline P4 & 0,815 & 0,196 & Valid \\
\hline P5 & 0,860 & 0,196 & Valid \\
\hline P6 & 0,861 & 0,196 & Valid \\
\hline
\end{tabular}


"Dari hasil uji validitas tersebut maka dapat dijelaskan bahwa keseluruhan nilai $\mathrm{r}_{\text {hitung }}$ lebih besar dari $r_{\text {tabel }}(0,196)$ dengan demikian dapat disimpulkan bahwa semua item pernyataan adalah valid".

\begin{tabular}{|c|c|c|c|}
\hline \multicolumn{4}{|c|}{ Tabel 3. Uji Validitas Promosi } \\
\hline Bulan & $r_{\text {hitung }}$ & $r_{\text {tbel }}$ & Keputusan \\
\hline P1 & 0,592 & 0,196 & Valid \\
\hline P2 & 0,833 & 0,196 & Valid \\
\hline P3 & 0,896 & 0,196 & Valid \\
\hline P4 & 0,863 & 0,196 & Valid \\
\hline P5 & 0,937 & 0,196 & Valid \\
\hline P6 & 0,957 & 0,196 & Valid \\
\hline P7 & 0,949 & 0,196 & Valid \\
\hline P8 & 0,942 & 0,196 & Valid \\
\hline P9 & 0,916 & 0,196 & Valid \\
\hline P10 & 0,784 & 0,196 & Valid \\
\hline
\end{tabular}

"Dari hasil uji validitas tersebut maka dapat dijelaskan bahwa keseluruhan nilai $\mathrm{r}_{\text {hitung }}$ lebih besar dari $\mathrm{r}_{\text {tabel }}(0,196)$ dengan demikian dapat disimpulkan bahwa semua item pernyataan adalah valid".

\begin{tabular}{c|c|c|c|}
\hline \multicolumn{5}{|c}{ Tabel 4. Uji Validitas Minat Beli } \\
\hline Bulan & $r_{\text {tabel }}$ & $r_{\text {tabel }}$ & Keputusan \\
\hline P1 & 0,674 & 0,196 & Valid \\
\hline P2 & 0,670 & 0,196 & Valid \\
\hline P3 & 0,832 & 0,196 & Valid \\
\hline P4 & 0,783 & 0,196 & Valid \\
\hline P5 & 0,631 & 0,196 & Valid \\
\hline P6 & 0,686 & 0,196 & Valid \\
\hline P7 & 0,718 & 0,196 & Valid \\
\hline P8 & 0,701 & 0,196 & Valid \\
\hline
\end{tabular}

"Dari hasil uji validitas tersebut maka dapat dijelaskan bahwa keseluruhan nilai $\mathrm{r}_{\text {hitung }}$ lebih besar dari $\mathrm{r}_{\text {tabel }}(0,196)$ dengan demikian dapat disimpulkan bahwa semua item pernyataan adalah valid".

\begin{tabular}{|c|c|c|c|}
\hline \multicolumn{4}{|c|}{ Tabel 5. Uji Validitas Keputusan Pembelian } \\
\hline Bulan & $\mathbf{r}_{\text {tabel }}$ & $\mathbf{r}_{\text {tabel }}$ & Keputusan \\
\hline P1 & 0,732 & 0,196 & Valid \\
\hline P2 & 0,726 & 0,196 & Valid \\
\hline P3 & 0,700 & 0,196 & Valid \\
\hline
\end{tabular}

\begin{tabular}{|c|c|c|c|}
\hline P4 & 0,58 & 0,196 & Valid \\
\hline P5 & 0,723 & 0,196 & Valid \\
\hline P6 & 0,793 & 0,196 & Valid \\
\hline P7 & 0,79 & 0,196 & Valid \\
\hline P8 & 0,587 & 0,196 & Valid \\
\hline P9 & 0,746 & 0,196 & Valid \\
\hline P10 & 0,711 & 0,196 & Valid \\
\hline
\end{tabular}

"Dari hasil uji validitas tersebut maka dapat dijelaskan bahwa keseluruhan nilai $\mathrm{r}_{\text {hitung }}$ lebih besar dari $\mathrm{r}_{\text {tabel }}(0,196)$ dengan demikian dapat disimpulkan bahwa semua item pernyataan adalah valid".

\section{Uji Reliabilitas}

"Uji reliabilitas dilakukan untuk menguji apakah jawaban dari responden konsisten atau stabil, suatu variabel dikatakan reliabel jika memiliki nilai Cronbach Alpha > 0,60" (Ghozali, 2016).

\begin{tabular}{|l|c|c|}
\hline \multicolumn{3}{c}{ Tabel 6. Hasil Uji Reliabilitas } \\
\hline \multicolumn{1}{c|}{ Variabel } & Cronbach Alpha & Keterangan \\
\hline Kepercayaan & 0,878 & Reliabel \\
\hline Promosi & 0,964 & Reliabel \\
\hline Minat Beli & 0,853 & Reliabel \\
\hline Keputusan Pembelian & 0,883 & Reliabel \\
\hline
\end{tabular}

"Berdasarkan Tabel 6, hasil uji reliabilitas diperoleh nilai-nilai Cronbach's Alpha semua variabel penelitian menunjukkan $>0,60$ maka dengan demikian jawaban-jawaban responden dari variabel-variabel penelitian tersebut adalah reliabel, sehingga semua butir pertanyaan dapat dipercaya dan dapat digunakan untuk penelitian selanjutnya".

\section{Uji Asumsi Klasik}

\section{Uji Normalitas}

"Untuk mengetahui apakah data berdistribusi normal atau mendekati normal bisa dilakukan uji statistik Kolmogrov-Smirnov (KS) tes, pengujian normalitas data dalam penelitian ini menggunakan one sample kolmogorov-smirnov test dengan syarat jika asympp sig (2-tailed) > 0,05 maka data tersebut berdistribusi normal. Sebaliknya jika asymp sig (2-tailed) $<0,05$ maka data tersebut berdistribusi tidak normal", (Ghozali, 2016). 


\begin{tabular}{|c|c|c|}
\hline \multicolumn{3}{|c|}{ One-Sample Kolmogorov-Smirnov Test } \\
\hline & & $\begin{array}{l}\text { Unstandardized } \\
\text { Residual }\end{array}$ \\
\hline \multicolumn{2}{|l|}{$\mathrm{N}$} & 100 \\
\hline \multirow[t]{2}{*}{ Normal Parameters $\mathrm{s}^{\mathrm{a}, \mathrm{b}}$} & Mean &, 0000000 \\
\hline & Std. Deviation & 5,08091707 \\
\hline \multirow[t]{3}{*}{ Most Extreme Differences } & Absolute & ,074 \\
\hline & Positive &, 039 \\
\hline & Negative &,- 074 \\
\hline \multicolumn{2}{|l|}{ Test Statistic } & .074 \\
\hline \multicolumn{2}{|l|}{ Asymp. Sig. (2-tailed) } & ,200.. \\
\hline \multicolumn{3}{|c|}{$\begin{array}{l}\text { a. Test distribution is Normal. } \\
\text { b. Calculated from data. } \\
\text { c. Lilliefors Significance Correction } \\
\text { d. This is a lower bound of the true significance }\end{array}$} \\
\hline
\end{tabular}

"Berdasarkan Tabel 7 uji normalitas persamaan 1 menunjukkan bahwa nilai Asymp. Sig. (2-tailed) sebesar 0,200 >0,05 hal ini berarti data dalam penelitian ini telah terdistribusi dengan normal".

\begin{tabular}{|c|c|c|}
\hline \multicolumn{3}{|c|}{ Tabel 8. Uji Normalitas Persamaan 2} \\
\hline \multicolumn{3}{|c|}{ One-Sample Kolmogorov-Smirnov Test } \\
\hline & & $\begin{array}{c}\text { Unstandardized } \\
\text { Residual }\end{array}$ \\
\hline \multicolumn{2}{|l|}{ N } & 100 \\
\hline \multirow[t]{2}{*}{ Normal Parameters ${ }^{\mathrm{a}, \mathrm{b}}$} & Mean &, 0000000 \\
\hline & Std. Deviation & 4,88871262 \\
\hline \multirow[t]{3}{*}{ Most Extreme Differences } & Absolute & .062 \\
\hline & Positive & ,046 \\
\hline & Negative &,- 062 \\
\hline \multicolumn{2}{|l|}{ Test Statistic } & ,062 \\
\hline \multicolumn{2}{|l|}{ Asymp. Sig. (2-tailed) } & ,200c.d \\
\hline \multicolumn{3}{|c|}{$\begin{array}{l}\text { a. Test distribution is Normal. } \\
\text { b. Calculated from data. } \\
\text { c. Lilliefors Significance Correction } \\
\text { d. This is a lower bound of the true significance }\end{array}$} \\
\hline
\end{tabular}

"Berdasarkan Tabel 8 uji normalitas persamaan 2 menunjukkan bahwa nilai Asymp. Sig. (2-tailed) sebesar 0,200 >0,05, hal ini berarti data dalam penelitian ini telah terdistribusi dengan normal".

\section{Uji Multikolinertias}

"Uji multikolineritas bertujuan untuk menguji apakah model regresi ditemukan adanya korelasi antar variabel bebas (Independen), model regresi yang baik seharusnya tidak terjadi korelasi diantara variabel bebas", (Ghozali, 2016).
Tabel 9. Uji Multikolinearitas Persamaan 1

\begin{tabular}{|c|l|c|c|}
\hline \multicolumn{2}{|c|}{ Model } & \multicolumn{2}{c|}{ Collinearity Statistics } \\
\cline { 3 - 4 } \multicolumn{2}{|c|}{} & Tolerance & VIF \\
\hline \multirow{2}{*}{1} & (Constant) & & \\
\cline { 2 - 4 } & Kepercayaan & 0,961 & 1,041 \\
\cline { 2 - 4 } & Promosi & 0,961 & 1,041 \\
\hline \multicolumn{2}{|l}{} \\
\hline
\end{tabular}

"Dari tabel 9 persamaan 1 terlihat bahwa semua variabel bebas memiliki nilai tolerance > 0.10 dan nilai VIF $<10$, sehingga semua variabel bebas tidak terdapat multikolinearitas".

\begin{tabular}{|c|c|c|c|}
\hline \multicolumn{4}{|c|}{ Tabel 10. Uji Multikolinearitas Persamaan 2} \\
\hline \multirow{2}{*}{\multicolumn{2}{|c|}{ Model }} & \multicolumn{2}{|c|}{ Collinearity Statistics } \\
\hline & & Tolerance & VIF \\
\hline \multirow[t]{4}{*}{1} & (Constant) & & \\
\hline & Kepercayaan & 0,697 & 1,436 \\
\hline & Promosi & 0,830 & 1,204 \\
\hline & Minat Beli & 0,603 & 1,659 \\
\hline
\end{tabular}

"Dari tabel 10 persamaan 2 terlihat bahwa semua variabel bebas memiliki nilai tolerance > 0.10 dan nilai $\mathrm{VIF}<10$, sehingga semua variabel bebas tidak terdapat multikolinearitas".

\section{Uji Heteroskedastisitas}

"Uji heteroskedastisitas bertujuan menguji apakah dalam model regresi terjadi ketidaksamaan variance dari residual satu pengamatan ke pengamatan yang lain", (Ghozali, 2016:139). Ada atau tidak adanya gejala heteros dengan melihat pada grafik berikut ini:

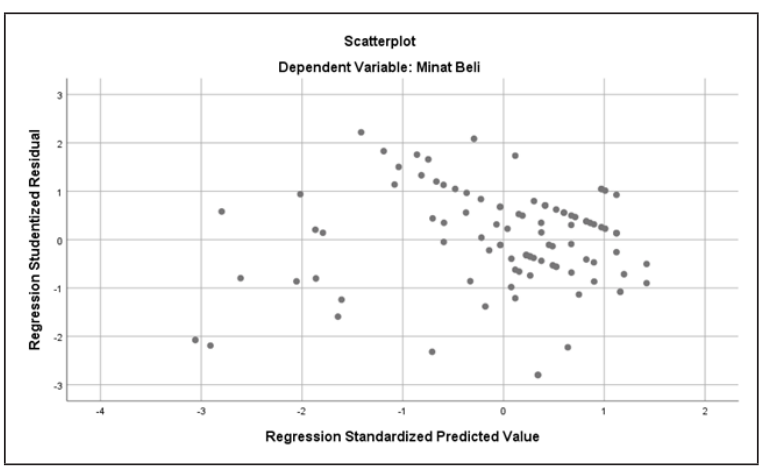

Gambar 3. Uji Heteroskedastisitas Persamaan 1

"Dari grafik tersebut, dapat terlihat titik-titik yang menyebar secara acak, tidak membentuk suatu pola tertentu yang jelas, serta tersebar baik di atas maupun di bawah angka 0 (nol) pada 
sumbu $\mathrm{Y}$, hal ini menunjukkan bahwa data dalam penelitian ini tidak terjadi heteroskedastisitas".

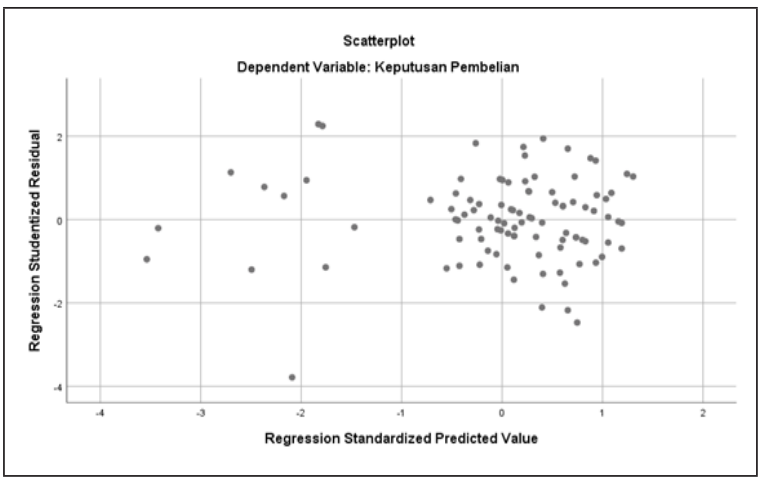

Gambar 4. Uji Heteroskedastisitas Persamaan 2

"Dari grafik tersebut, dapat terlihat titik-titik yang menyebar secara acak, tidak membentuk suatu pola tertentu yang jelas, serta tersebar baik di atas maupun di bawah angka 0 (nol) pada sumbu Y, hal ini menunjukkan bahwa data dalam penelitian ini tidak terjadi heteroskedastisitas".

\section{Persamaan Sub Struktur 1}

\begin{tabular}{|c|c|c|c|c|c|c|}
\hline \multicolumn{7}{|c|}{ Tabel 11. Koefisien Jalur Tahap 1} \\
\hline \multirow{2}{*}{\multicolumn{2}{|c|}{ Model }} & \multicolumn{2}{|c|}{$\begin{array}{l}\text { Unstandardized } \\
\text { Coefficients }\end{array}$} & \multicolumn{3}{|c|}{ Standardized Coefficients } \\
\hline & & B & $\begin{array}{l}\text { Std. } \\
\text { Error }\end{array}$ & Beta & $t$ & Sig. \\
\hline \multirow{3}{*}{1} & (Constant) & 11,609 & 2,461 & & 4,716 & 0,000 \\
\hline & Kepercayaan & 0,617 & 0,102 & 0,488 & 6,066 & 0,000 \\
\hline & Promosi & 0,153 & 0,039 & 0,314 & 3,902 & 0,000 \\
\hline
\end{tabular}

Persamaan hasil analisis jalur yang terbentuk adalah: $\mathrm{Y}=11,609+0,488 \mathrm{X}_{1}+0,314 \mathrm{X}_{2}$

1. Nilai konstanta sebesar 11,609 artinya apabila kepercayaan dan promosi tidak meningkat maka minat beli akan tetap bernilai 11,609.

2. Nilai koefisien beta 0,488 (positif) menunjukkan pengaruh yang searah yang artinya jika tingkat kepercayaan pelanggan meningkat akan membuat peningkatan minat beli sebesar 0,488.

3. Nilai koefisien beta 0,314 (positif) menunjukkan pengaruh yang searah yang artinya jika tingkat promosi semakin menarik akan membuat peningkatan minat beli sebesar 0,314 .

\begin{tabular}{l}
\hline \multicolumn{5}{|c|}{ Tabel 12. Koefisien Determinasi Persamaan 1 } \\
\begin{tabular}{|c|c|c|c|c|}
\hline Model & R & R Square & $\begin{array}{c}\text { Adjusted } \\
\text { R Square }\end{array}$ & $\begin{array}{c}\text { Std. Error of } \\
\text { the Estimate }\end{array}$ \\
\hline 1 &, $630^{\mathrm{a}}$ & 0,397 & 0,385 & 5,13303 \\
\hline
\end{tabular} \\
$\begin{array}{l}\text { a. Predictors: (Constant), Promosi, Kepercayaan } \\
\text { b. Dependent Variabel: Minat Beli }\end{array}$ \\
\hline
\end{tabular}

Dari Tabel 12, diperoleh bahwa nilai Rsquare dari 0,397 berarti bahwa 39,7\% dari variabel minat beli pelanggan dipengaruhi oleh variabel kepercayaan dan promosi, sedangkan sisanya $60,3 \%$ dijelaskan oleh faktor-faktor lain yang tidak termasuk dalam model. Kemudian mencari nilai error dengan rumus :

$$
\begin{aligned}
& e 1=\sqrt{1-0,397} \\
& e 1=\sqrt{0,603} \\
& e 1=0,776
\end{aligned}
$$

\begin{tabular}{|c|c|c|c|c|c|c|}
\hline \multicolumn{7}{|c|}{ Tabel 13. Hasil Uji F Persamaan 1} \\
\hline \multicolumn{2}{|c|}{ Model } & Sum of & Df & Mean & $F$ & Sig. \\
\hline \multirow{3}{*}{1} & Regression & 1683,634 & 2 & 841,817 & 31,950 & $.000^{\mathrm{b}}$ \\
\hline & Residual & 2555,756 & 97 & 26,348 & & \\
\hline & Total & 4239,390 & 99 & & & \\
\hline
\end{tabular}

Hasil di atas menunjukkan bahwa nilai signifikansi lebih rendah dari angka 0,05 atau $(0,000<0,05)$, sehingga pemilihan variabel kepercayaan dan promosi telah tepat untuk dapat menjelaskan variabel minat beli.

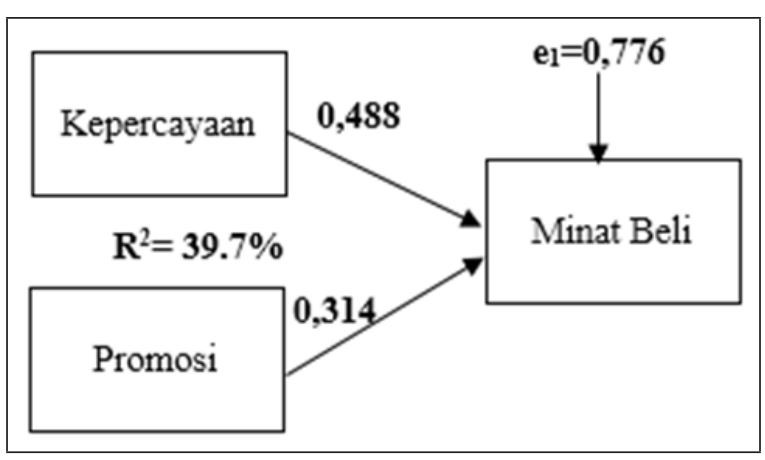

Gambar 5. Analisis Jalur Tahap 1

Mengamati tabel dan gambar di atas, persamaan jalur tahap pertama berikut diperoleh persamaannya: $\mathrm{Y}=0,488 \mathrm{X}_{1}+0,314 \mathrm{X}_{2}+0,776$ 


\section{Persamaan Sub Struktur 2}

\begin{tabular}{|c|c|c|c|c|c|c|}
\hline \multicolumn{7}{|c|}{ Tabel 14. Koefisien Jalur Tahap 2} \\
\hline \multirow{2}{*}{\multicolumn{2}{|c|}{ Model }} & \multicolumn{2}{|c|}{$\begin{array}{l}\text { Unstandardized } \\
\text { Coefficients }\end{array}$} & \multicolumn{3}{|c|}{ Standardized Coefficients } \\
\hline & & B & $\begin{array}{l}\text { Std. } \\
\text { Error }\end{array}$ & Beta & $t$ & Sig. \\
\hline \multirow{4}{*}{1} & (Constant) & 12,211 & 2,639 & & 4,626 & 0,000 \\
\hline & Kepercayaan & 0,576 & 0,115 & 0,423 & 4,987 & 0,000 \\
\hline & Promosi & 0,103 & 0,041 & 0,197 & 2,531 & 0,013 \\
\hline & Minat Beli & 0,315 & 0,098 & 0,293 & 3,902 & 0,002 \\
\hline
\end{tabular}

Persamaan hasil analisis jalur yang terbentuk adalah: $\mathrm{Z}=12,211+0,423 \mathrm{X}_{1}+0,197 \mathrm{X}_{2}+0,293 \mathrm{Y}$

1. Nilai konstanta sebesar 12,211 menunjukkan bahwa apabila kepercayaan, promosi dan minat beli tidak mengalami perubahan maka keputusan pembelian akan tetap bernilai 12,211 .

2. Nilai koefisien beta 0,423 (positif) menunjukkan pengaruh yang searah yang artinya jika tingkat kepercayaan pelanggan dinaikan akan membuat peningkatan keputusan pembelian sebesar 0,423.

3. Nilai koefisien beta 0,197 (positif) menunjukkan pengaruh yang searah yang artinya jika tingkat promosi dinaikan akan membuat peningkatan keputusan pembelian sebesar 0,197 .

4. Nilai koefisien beta 0,293 (positif) menunjukkan pengaruh yang searah yang artinya jika tingkat minat beli pelanggan dinaikan akan membuat peningkatan keputusan pembelian sebesar 0,293.

\begin{tabular}{l}
\hline \multicolumn{1}{|c|}{ Tabel 15. Koefisien Determinasi Persamaan 2} \\
\begin{tabular}{|c|c|c|c|c|}
\hline Model & $\mathbf{R}$ & R Square & $\begin{array}{c}\text { Adjusted } \\
\text { R Square }\end{array}$ & $\begin{array}{c}\text { Std. Error of } \\
\text { the Estimate }\end{array}$ \\
\hline 1 &, $721^{\text {a }}$ & 0,519 & 0,504 & 4,96451 \\
\hline
\end{tabular} \\
$\begin{array}{l}\text { a. Predictors: (Constant), Minat Beli, Promosi, Kepercayaan } \\
\text { b. Dependent Variabel: Keputusan Pembelian }\end{array}$ \\
\hline
\end{tabular}

Dari tabel 15 diperoleh nilai Rsquare 0,519 mempunyai arti bahwa sebesar $51,9 \%$ dari variabel keputusan pembelian dipengaruhi oleh variabel kepercayaan, promosi dan minat beli, sedangkan sisanya $48,1 \%$ dijelaskan oleh faktor-faktor lain yang tidak termasuk dalam model peneitian ini. Kemudian mencari nilai error dengan rumus:

$$
\begin{aligned}
& e 2=\sqrt{1-0,519} \\
& e 2=\sqrt{0,481} \\
& e 2=0,693
\end{aligned}
$$

\begin{tabular}{l}
\hline \multicolumn{7}{|c|}{ Tabel 16. Hasil Uji F Persamaan 2 } \\
\begin{tabular}{|l|l|c|c|c|c|c|}
\hline \multicolumn{2}{|l|}{ Model } & $\begin{array}{c}\text { Sum of } \\
\text { Squares }\end{array}$ & Df & $\begin{array}{c}\text { Mean } \\
\text { Square }\end{array}$ & F & Sig. \\
\hline \multirow{2}{*}{1} & Regression & 2554,388 & 3 & 851,462 & 34,547 & $.000^{\circ}$ \\
\cline { 2 - 7 } & Residual & 2366,052 & 96 & 24,646 & & \\
\cline { 2 - 7 } & Total & 4920,440 & 99 & & & \\
\hline
\end{tabular} \\
$\begin{array}{l}\text { a. Dependent Variabel: Keputusan Pembelian } \\
\text { b. Predictors: IConstant), Minat Beli, Promosi, Kepercayaan }\end{array}$ \\
\hline
\end{tabular}

Hasil di atas menunjukkan bahwa angkaa signifikansii lebih kecil dan lebih rendah dari 0,05 atau $(0,000<0,05)$, sehingga pemilihan variabel kepercayaan, promosi dan minat beli telah sesuai dan tepat untuk dapat menjelaskan variabel keputusan pembelian. Berikut ini adalah gambar persamaan sub-struktur 2 .

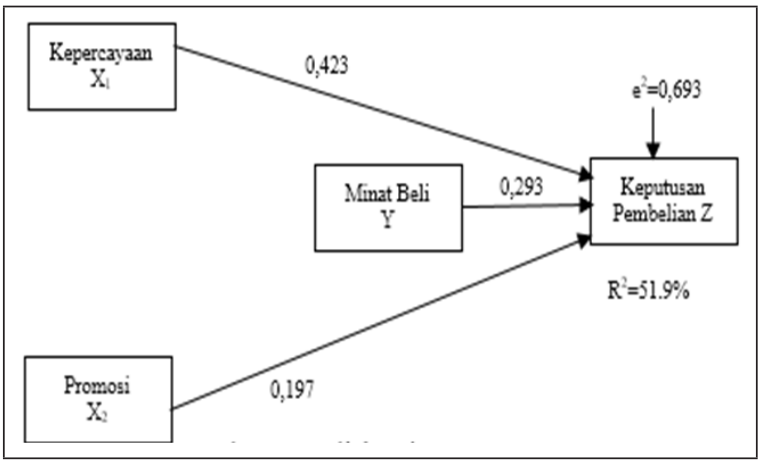

Gambar 6. Analisis Jalur Tahap 2

Mengamati tabel dan gambar 6 di atas, persamaan jalur tahap kedua maka berikut diperoleh persamaannya: $\mathrm{Z}=0,423 \mathrm{X}_{1}+0,197 \mathrm{X}_{2}$ $+0,293 \mathrm{Y}+0,693$

Hubungan kausalitas antar variabel secara keseluruhan dari hasil pengujian statistik atau gabungan dari persamaan pertama dan kedua maka dapat dilihat pada gambar sebagai berikut:

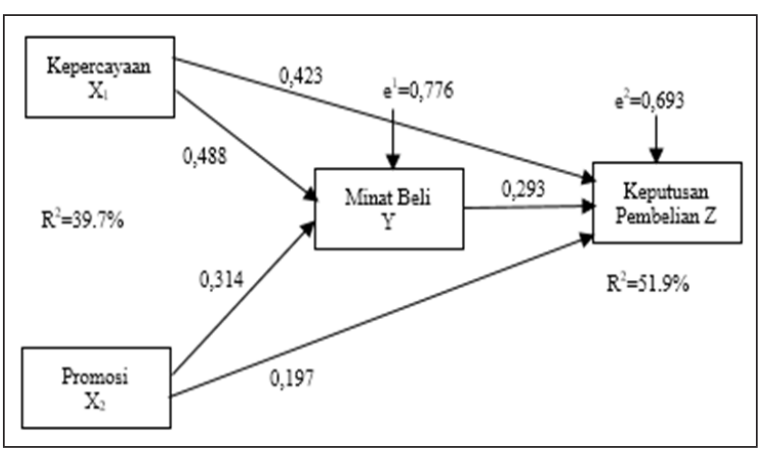

Gambar 7. Full Model Analisis Jalur 
Berdasarkan diagram jalur pada Gambar 7. Maka dapat dihitung besarnya pengaruh langsung, pengaruh tidak langsung serta pengaruh total antar variabel. Menurut Ghozali (2016), "untuk mengetahui pengaruh tidak langsungnya sebuah jalur dengan cara mengalikan koefisien tidak langsungnya". Perhitungan pengaruh antar variabel dirangkum dalam Tabel 17:

Tabel 17. Pengaruh Langsung, Tidak Langsung, dan Pengaruh Total

\begin{tabular}{|c|c|c|c|}
\hline Pengaruh & Pengaruh Langsung & $\begin{array}{c}\text { Pengaruh Tidak } \\
\text { Langsung }\end{array}$ & Pengaruh Total \\
\hline$X_{1}-Y$ & 0,488 & - & 0,488 \\
\hline$X_{2}-Y$ & 0,314 & - & 0,314 \\
\hline$Y-Z$ & 0,293 & - & 0,293 \\
\hline$X_{1}-Z$ & 0,423 & - & 0,423 \\
\hline$X_{2}-Z$ & 0,197 & - & 0,197 \\
\hline$X_{1}-Y-Z$ & - & 0,142 & 0,06 \\
\hline$X_{2}-Y-Z$ & - & 0,092 & 0,018 \\
\hline
\end{tabular}

\section{Hasil Uji Sobel}

Dalam analisis jalur untuk mengetahui apakah pengaruh mediasi siggnifikann atau tidak, diuji dengan sobel test sebagai berikut:

$$
\mathrm{Z}=\frac{a b}{\sqrt{b^{2} S a^{2}+a^{2} S b^{2}+S a^{2} S b^{2}}}
$$

"Bila nilai kalkulasi $\mathrm{Z}$ lebih besar dari 1,96 (dengan tingkat kepercayaan 95 persen), maka variabel mediasi dinilai secara signifikan memediasi hubungan antara variabel eksogen dan variabel endogen". (Ghozali, 2016). Dengan menggunakan alat bantu Excel sebagai alat untuk menghitung uji Sobel maka diperoleh hasil sebagai berikut:

Kepercayaan memiliki nilai $Z=2,492$

Promosi memiliki nilai $Z=2,77$

\section{Hipotesis 1}

Berdasarkan hasil pengujian statistik pada tabel 11 angka dari $\mathrm{t}_{\text {hitung }} 6,066>\mathrm{t}_{\text {tabel }} 1,984$ dengan angka sig 0,000 lebih rendah dan kecil dari 0,05 menunjukkan diterimanya $\mathrm{H}_{1}$ dan ditolaknya $\mathrm{H}_{01}$ yang berarti bahwa kepercayaan pelanggan memiliki pengaruh positif dan signifikan terhadap minat beli.

\section{Hipotesis 2}

Berdasarkan hasil pengujian statistik pada tabel 11 angka dari $\mathrm{t}_{\text {hitung }} 3,902>\mathrm{t}_{\text {tabel }} 1,984$ dengan angka sig 0,000 lebih rendah dan kecil dari 0,05 menunjukkan diterimanya $\mathrm{H}_{2}$ dan ditolaknya $\mathrm{H}_{02}$ yang berarti bahwa promosi berpengaruh positif dan signifikan terhadap mminat belli.

\section{Hipotesis 3}

Berdasarkan hasil pengujian statistik pada tabel 14 angka dari $\mathrm{t}_{\text {hitung }} 3,209>\mathrm{t}_{\text {tabel }}$ 1,984 dengan angka sig 0,002 lebih rendah dan kecil dari 0,05 menunjukkan diterimanya $\mathrm{H}_{3}$ dan ditolaknya $\mathrm{H}_{03}$ yang berarti bahwa minat beli berpengaruh positif dan signifikan terhadap keputusan pembelian.

\section{Hipotesis 4}

Berdasarkan hasil pengujian statistik pada tabel 14 angka dari $\mathrm{t}_{\text {hitung }} 4,987>\mathrm{t}_{\text {tabel }} 1,984$ dengan angka sig 0,000 lebih rendah dan kecil dari 0,05 menunjukkan diterimanya $\mathrm{H}_{4}$ dan ditolaknya $\mathrm{H}_{04}$ yang berarti bahwa kepercayaan pelanggan berpengaruh positif dan signifikan terhadap keputusan pembelian.

\section{Hipotesis 5}

Berdasarkan hasil pengujian statistik pada tabel 14 angka dari $\mathrm{t}_{\text {hitung }} 2,531>\mathrm{t}_{\text {tabel }} 1,984$ dengan angka sig 0,013 lebih rendah dan kecil dari 0,05 menunjukkan diterimanya $\mathrm{H}_{5}$ dan ditolaknya $\mathrm{H}_{05}$ yang berarti bahwa promosi berpengaruh positif dan signifikan terhadap keputusan pembelian.

\section{Hipotesis 6}

Berdasarkan hasil pengujian statistik perhitungan dengan menggunakan uji sobel, menunjukkan nilai $\mathrm{Z}$ sebesar 2,492 > 1,96. Ini berarti bahwa variabel mediasi yaitu minat beli dinilai mampu dan dapat memediasi pengaruh dari variabel kepercayaan pelanggan terhadap keputuan pembelian.

\section{Hipotesis 7}

Berdasarkan hasil pengujian statistik perhitungan dengan menggunakan uji sobel, menunjukkan nilai $Z$ sebesar 2,77 > 1,96. Ini berarti bahwa variabel mediasi yaitu minat beli dinilai mampu dan dapat memediasi pengaruh dari variabel promosi terhadap keputuan pembelian. 


\section{Pembahasan}

\section{Pengaruh Kepercayaan Terhadap Minat Beli}

Hasil uji hipotesis $\left(\mathrm{H}_{1}\right)$ menunjukkan bahwa kepercayaan pelanggan memiliki pengaruh positif dan signifikan terhadap minat beli. Ini berarti bahwa semakin tinggi tingkat kepercayaan pelanggan, semakin tinggi minat pelanggan untuk membeli. Kepercayaan positif tentu sangat dapat mempengaruhi perilaku minat konsumen dalam berbelanja online, karena mereka percaya dan yakin bahwa penjual yang dapat melakukan bisnisnya dengan benar dan bahwa ia dapat dipercaya dengan mengirimkan konsumen produk yang telah ia beli telah sesuai dengan harapan mereka akan dapat meningkatkan minat beli secara terus menerus.

Hasil penelitian ini sejalan dengan penelitian yang dilakukan oleh Idris (2018), yang menyatakan bahwa "variabel kepercayaan konsumen memiliki pengaruh positif terhadap minat beli".

\section{Pengaruh Promosi Terhadap Minat Beli}

Hasil pengujian hipotesis $\left(\mathrm{H}_{2}\right)$ membuktikan bahwa promosi memiliki pengaruh positif dan signifikan terhadap minat beli. Hal ini berarti semakin tinggi promosi yang dilakukan dan semakin menarik maka akan semakin tinggi juga minat beli pelanggan. Simamora (2011:754) menyatakan bahwa "promosi adalah pengkomunikasian informasi antara penjualan dan pembeli potensial atau pihak-pihak lainnya dalam saluran distribusi guna mempengaruhi sikap dan perilaku".

Hasil penelitian ini sesuai dan sejalan dengan penelitian yang dilakukan oleh Idris (2018), yang dalam penelitiannya bahwa "promosi memiliki pengaruh positif terhadap minat beli".

\section{Pengaruh Minat Beli}

\section{Terhadap Keputusan Pembelian}

Hasil pengujian hipotesis $\left(\mathrm{H}_{3}\right)$ membuktikan bahwa minat beli memiliki pengaruh positif dan signifikan terhadap keputusan pembelian. Hal ini berarti semakin tinggi minat beli pelanggan maka akan semakin tinggi juga keputusan pembelian konsumen. "Minat beli merupakan kecenderungan konsumen untuk membeli suatu merek atau mengambil tindakan yang berhubungan dengan pembelian yang diukur dengan tingkat kemungkinan konsumen melakukan pembelian", (Assael, 2004:51).

Hasil penelitian ini sejalan dengan penelitian yang dilakukan oleh Wicaksono (2017), minat beli berpengaruh positif dan signifikan terhadap keputusan pembelian.

\section{Pengaruh Kepercayaan \\ Terhadap Keputusan Pembelian}

Hasil pengujian hipotesis $\left(\mathrm{H}_{4}\right)$ membuktikan bahwa kepercayaan pelanggan memiliki pengaruh positif dan signifikan terhadap keputusan pembelian. Hal ini berarti semakin tinggi tingkat kepercayaan pelanggan maka akan semakin tinggi juga keputusan pembelian. Gefen (2013) menyimpulkan bahwa "semakin tinggi derajat kepercayaan konsumen, semakin tinggi tingkat pembelian niat konsumen". Dalam bisnis e-commerce kepercayaan pelanggan mutlak diperlukan tujuannya memberikan rasa aman dan ketenangan kepada pelanggan dalam melakukan transaksi. Apabila kepercayaan pelanggan sudah terbentuk dapat dipastikan mereka akan melakukan pembelian secara berulang.

Hasil penelitian ini sejalan dengan penelitian yang dilakukan oleh Natalia Siow (2013), yang menyatakan bahwa "Kepercayaan pelanggan secara parsial berpengaruh terhadap keputusan pembelian". Tajudin dan Mulazid (2017), juga menyatakan hal yang sama dalam penelitian yang dilakukannya bahwa "kepercayaan berpengaruh signifikan terhadap keputusan pembelian".

\section{Pengaruh Promosi}

\section{Terhadap Keputusan Pembelian}

Hasil pengujian hipotesis $\left(\mathrm{H}_{5}\right)$ membuktikan bahwa promosi memiliki pengaruh positif dan signifikan terhadap keputusan pembelian. Ini berarti bahwa semakin tinggi tingkat promosi, semakin tinggi keputusan pembelian. Promosi menarik mendorong banyak konsumen untuk membeli produk. Karena iklan yang menarik di benak konsumen membuat konsumen memutuskan untuk membeli suatu produk. Menurut Alma (2015:187), "Promosi dilakukan secara 
menarik agar lebih menarik perhatian pelanggan untuk membeli produk dan jasa yang disediakan, dengan cara ini dapat menimbulkan pelanggan yang loyal dikarenakan pelanggan dapat tertarik dengan promosi penjualan yang dilakukan".

Hasil penelitian ini sejalan dengan penelitian yang dilakukan oleh Tajudin dan Mulazid (2017), yang menyatakan bahwa "secara parsial promosi berpengaruh signifikan terhadap keputusan pembelian".

\section{Pengaruh Kepercayaan Terhadap Keputusan Pembelian Melalui Minat Beli}

Hasil pengujian hipotesis $\left(\mathrm{H}_{6}\right)$ membuktikan bahwa variabel mediasi yaitu Minat beli mampu memediasi pengaruh kepercayaan pelanggan terhadap keputusan pembelian.

Hasil penelitian ini tidak sejalan dengan penelitian yang dilakukan oleh Dewi, Yulianeu, Haryono dan Gagah (2017), yang menyatakan "Minat beli bukan variabel intervening yang memediasi pengaruh kepercayaan terhadap keputusan pembelian online".

\section{Pengaruh Promosi Terhadap}

\section{Keputusan Pembelian Melalui Minat Beli}

Hasil pengujian hipotesis $\left(\mathrm{H}_{7}\right)$ membuktikan bahwa variabel mediasi yaitu Minat beli mampu memediasi pengaruh promosi terhadap keputuan pembelian.

Hasil penelitian ini sejalan dengan penelitian yang dilakukan oleh Fira (2018), "promosi berpengaruh signifikan melalui minat beli terhadap keputusan pembelian".

\section{SIMPULAN}

Kepercayaan pelanggan berpengaruh positif dan signifikan terhadap minat beli pada Online Shop Mikaylaku, hasil penelitian ini membuktikan bahwa semakin tinggi tingkat kepercayaan pelanggan maka akan semakin tinggi minat beli pelanggan. Promosi berpengaruh positif dan signifikan terhadap minat beli pada Online Shop Mikaylaku. hasil penelitian ini membuktikan bahwa semakin tinggi promosi yang dilakukan maka akan semakin tinggi minat beli pelanggan untuk berbelanja. Minat beli berpengaruh positif dan signifikan terhadap keputusan pembelian Pada Online Shop Mikaylaku, hasil penelitian ini membuktikan bahwa semakin tinggi minat beli maka semakin tinggi pula keputusan pembelian. Kepercayaan pelanggan berpengaruh positif dan signifikan terhadap keputusan pembelian pada Online Shop Mikaylaku, hasil penelitian ini membuktikan bahwa semakin tinggi tingkat kepercayaan pelanggan maka akan semakin tinggi keputusan pembelian. Promosi berpengaruh positif dan signifikan terhadap keputusan pembelian oada Online Shop Mikaylaku, hasil penelitian ini membuktikan bahwa semakin tinggi promosi yang dilakukan maka akan semakin tinggi keputusan pembelian pelanggan untuk berbelanja. Minat beli mampu memediasi pengaruh kepercayaan pelanggan terhadap keputuan pembelian pada Online Shop Mikaylaku, artinya dalam penelitian ini terbukti bahwa kepercayaan dapat mempengaruhi keputusan pembelian dari pelanggan Online Shop Mikaylaku maka harus menggunakan mediasi minat beli. Minat beli Minat beli mampu memediasi pengaruh promosi terhadap keputuan pembelian pada Online Shop Mikaylaku, artinya dalam penelitian ini terbukti bahwa promosi dapat mempengaruhi keputusan pembelian dari pelanggan Online Shop Mikaylaku maka harus menggunakan mediasi minat beli.

\section{PENGHARGAAN}

Penulis menyampaikan penghargaan kepada pemilik Online Shop Mikaylaku Bapak Revien Hans Christian Iskandar, S.E., M.M., yang telah mengijinkan penulis dan memberikan data-data yang dibutuhkan sehingga penulis dapat menyelesaikan penelitian ini.

\section{DAFTAR PUSTAKA}

Assael, H. (2004), Consumers Behavior and Marketing Action, Edisi 3, South Western College. Publishing.

Barnes, J. G. (2013). Secerets of Customer Relationship Management. Jakarta: Penerbit Andi. 
Bilson, S. (2011). Memenangkan Pasar dengan Pemasaran Efektif dan Profitabel. Jakarta: PT. Gramedia Pustaka Utama.

Chen, S. C., \& Dhillon, G. S. (2003). Interpreting Dimensions of Consumer Trust in eCommerce, Information Technology and Management, 4,303-318.

Cheng, B. L., \& Yee, S W. (2014). Factors Influencing Consumers' Online Purchase Intention: A Study among University Students in Malaysia, International Journal of Liberal Arts and Social Science Vol. 2 No. 8.

David, W. (2017), Pengaruh Ability, Benevolence Dan Integrity Terhadap Trust, Serta Implikasinya Terhadap Partisipasi Pelanggan E-Commerce: Studi Kasus Pada Pelanggan Ecommerce Di UBM. Jurnal Riset Manajemen dan Bisnis (JRMB) Fakultas Ekonomi UNIAT. Vol. 2, No. 2.

Dewi, dkk. (2017). Pengaruh Kepercayaan Konsumen, Kemudahan Dan Kualitas Informasi Terhadap Keputusan Pembelian Secara Online Dengan Minat Beli Sebagai Variabel Intervening (Studi Pada Pengguna Situs Jual Beli Bukalapak.Com). Journal of Management. Vol. 3. No. 3.

Eggert, A. (2006). Intangibility and perceived risk in online environments, Academy of Marketing, London: University of Middlesex.

Ferdinand, A. (2006). Metode Penelitian Mananjemen: Pedoman Penelitian untuk Penulisan skripsi, Tesis, dan disertasi Ilmu Manajemen. Semarang: Badan Penerbit Universitas Diponegoro.

Fira, D. A. (2018). Pengaruh Marketing Mix Terhadap Keputusan Pembelian Kecap Cap Ikan Gurami Melalui Minat Beli Konsumen Sebagai Variabel Intervening Di PT Azafood Blitar. IAIN Tulung Agung.

Gefen, D., \& Straub, D. (2004). Managing User Trust in B2C e-Services, e-Service Journal, (2): 7-24.

Ghozali, I. (2016). Aplikasi Analisis Multivariete Dengan Program. IBM SPSS 23 (Edisi 8). Cetakan ke VIII. Semarang: Badan Penerbit Universitas Diponogoro.

Idris, A. W. (2018), Pengaruh Promosi, Kemudahan
Penggunaan, Kepercayaan Konsumen Dan Kualitas Informasi Terhadap Minat Beli Di Situs Bukalapak (Pada Mahasiswa Universitas Diponegoro), Diponegoro Journal Ofmanagement, Volume 7, Nomor 2.

Julian, C. (2014), Sales Promotion, Jakarta: PPM. Kotler, P., \& Kevin, K. L. (2016). Marketing Management 16 edition. New Jersey: Pearson. Kotler, P., \& Amstrong, G. (2016). Prinsip-prinsip Pemasaran. Edii13. Jilid 1. Jakarta: Erlangga.

Mowen, J. C., \& Micheal, M. (2012). Perilaku Konsumen. Jakarta: Erlangga.

Mursid. (2015). Manajemen Pemasaran. Jakarta: Bumi Aksara.

Natalia, S. (2013). Kualitas Layanan Dan Kepercayaan Pelanggan Pengaruhnya terhadap Keputusan Pembelian Sepeda Motor Suzuki Satria Fu150 Di Kota Manado. Jurnal EMBA. Vol.1 No.3.

Schiffman, \& Kanuk, (2015). Consumer Behavior. 11th Edition. Global Edition.

Sugiyono. (2016). Metode Penelitian Kuantitatif, Kualitatif dan R\&D. Bandung: PT Alfabeta.

Tajudin, M. H., dan Ade S. M. (2017), Pengaruh Promosi, Kepercayaan Dan Kesadaran Merek Terhadap Keputusan Nasabah Menggunakan Produk Tabungan Haji (Mabrur) Bank Syariah Mandiri Kcp. Sawangan Kota Depok. Jurnal Ekonomi Islam. Volume 8 No. 1.

Tjiptono, F. (2015). Strategi Pemasaran. Edisi 4. Jakarta: Penerbit Andi.

Wicaksono, P. U. M. (2017), Analisis Pengaruh Kualitas Produk, Persepsi Harga, Promosi Terhadap Citra Merek Dan Minat Beli Serta Dampaknya Pada Keputusan Pembelian Kartu Perdana XL Axiata Di Semarang. Diponegoro Journal Ofmanagement, Volume 6, Nomor 2.

Zeng, T., \& Onn, C. Y. (2015). Factors Affecting Purchase Intention of Online Shopping. Department of Business, Universiti Tunku Abdul Rahman, Malaysia British Journal of Economics, Management \& Trad: 1-12, 2015. 